\title{
A Possible Role of the Brain Angiotensin II Receptor Binding in Development of Hypertension
}

\author{
Kenji Mizuno, M.D. and SoItsu Fukuchi, M.D.
}

\begin{abstract}
To clarify a role of brain angiotensin II receptor binding in development of hypertension, the regional distribution and extent of specific angiotensin II binding were studied in salt-loaded normotensive (NTR) and spontaneously hypertensive (SHR) rats, and Goldblatt one-kidney hypertensive rat (GB). Further, angiotensin-converting enzyme activity was measured in these rats' brains.

In control rats, angiotensin II receptor binding was consistently lower in the thalamus, hypothalamus, midbrain, striatum and cortex of SHR rats than in NTR rats. In GB rats, the binding capacity in the thalamus was greater than that of NTR rats.

Sodium intake resulted in a rise in the receptor binding capacity in the hypothalamus, thalamus and striatum of SHR rat, whereas it did in a fall in the binding capacity in the hypothalamus, thalamus, striatum, midbrain and cortex of NTR rats. Angiotensin-converting enzyme activity was significantly elevated in the midbrain of salt-loaded SHR rats.
\end{abstract}

$\mathbf{T}$

HERE is considerable interest in the role of brain angiotensin II in the maintenance of blood pressure!,2 When administered into the ventricle, angiotensin II shows a potent pressor effect exerted by the release of antidiuretic hormone and increased sympathetic discharge ${ }^{3}$ and also induces a drinking response. ${ }^{4}$ However, the physiological and/or pathological significance of the brain renin-angiotensin system is still in dispute. 5 Previously we reported that, in spontaneously hypertensive rat as a model for essential hypertension of humans, the enhancement of

Key Words:

Angiotensin II receptor

Brain

Hypertension

Angiotensin-converting enzyme activity

Salt intake

Spontaneously hypertensive rat

Goldblatt one-kidney hypertensive rat maximal binding capacity of angiotensin II receptor was a possible mechanism in an occurrence or a development of hypertension observed in these rats.

In the present report, we have studied the regional distribution and extent of specific angiotensin II binding in the brain of spontaneously hypertensive and normotensive rats by using a previously described radioligand receptor assay for angiotensin II6 In addition, we have investigated the changes in the receptor binding and activity of angiotensin-converting enzyme of the brain in salt-loaded normotensive and spontaneously hypertensive rats, and in Goldblatt onekidney rat as a model for renal hypertension.

\section{MATERIALS AND METHODS}

Rats

1) Salt-Loaded Group

Female normotensive rats from Wistar-Kyoto

The Third Department of Internal Medicine, Fukushima Medical College, Fukushima, Japan

This study was supported by grant-in-aid for scientific research from Ministry of Education (No.577305).

Address for reprints: Kenji Mizuno, M.D., The Third Department of Internal Medicine, Fukushima Medical College, 4-45 Sugitsuma-cho, Fukushima-shi, Fukushima 960, Japan 
TABLE I SPECIFIC ANGIOTENSIN II BINDING ACTIVITY IN THE BRAIN REGIONS OF NORMOTENSIVE AND SPONTANEOUSLY HYPERTENSIVE RATS

\begin{tabular}{|c|c|c|c|c|c|}
\hline \multirow[t]{2}{*}{ Brain region } & \multirow{2}{*}{$\begin{array}{l}\text { Number of } \\
\text { experiments }\end{array}$} & \multicolumn{2}{|c|}{$\begin{array}{l}\text { Maximal binding capacity } \\
\text { (fmol/mg of protein) }\end{array}$} & \multicolumn{2}{|c|}{$\begin{array}{l}\text { Binding affinity } \\
(n M)\end{array}$} \\
\hline & & $\operatorname{NTR}(n=10)$ & $S H R(n=10)$ & $N T R(n=10)$ & $\operatorname{SHR}(n=10)$ \\
\hline Cerebral cortex & 3 & $1.3 \pm 0.9$ & $0.8 \pm 0.2$ & $0.76 \pm 0.02$ & $0.77 \pm 0.03$ \\
\hline Midbrain & 4 & $2.4 \pm 0.7$ & $1.9 \pm 0.2$ & $0.81 \pm 0.01$ & $0.76 \pm 0.05$ \\
\hline Thalamus & 4 & $3.0 \pm 1.1$ & $2.2 \pm 0.8$ & $0.80 \pm 0.02$ & $0.82 \pm 0.02$ \\
\hline Hypothalamus & 4 & $2.6 \pm 0.8$ & $2.4 \pm 0.2$ & $0.78 \pm 0.05$ & $0.74 \pm 0.04$ \\
\hline Striatum & 3 & $1.8 \pm 0.5$ & $1.5 \pm 0.7$ & $0.77 \pm 0.05$ & $0.76 \pm 0.03$ \\
\hline
\end{tabular}

Each value is mean \pm SEM. $\quad$ NTR = normotensive rat,$\quad S H R=$ spontaneously hypertensive rat,

Number of parentheses is number of rat examined.

strain and spontaneously hypertensive rats, aged 20-21 weeks, were used. Each was divided into a control group, given stock chow containing approximately $0.03 \% \mathrm{NaCl}$ (Oriental Co., Tokyo, Japan) and distilled water ad libitum, and an experimental group allowed to drink $1.0 \% \mathrm{NaCl}$ solution for a period of 4 weeks.

2) Goldblatt One-Kidney Group

Female normotensive rats from Wistar-Kyoto strain, aged 20 weeks, were anesthetized with ether and a silver clip ( $0.2 \mathrm{~mm}$ inside diameter) was placed on the left renal artery through a flank incision. The contralateral kidney was excised. After this, the rats were given the same stock chow described above and distilled water ad libitum for a period of 4 weeks.

In these rats body weights were determined and tail blood pressure was measured with an ultrasound device (Programmed Electrosphygmomanometer, PE 300, Narco) every week.

\section{Brain Radioligand Angiotensin II Receptor Assay}

Assays were carried out as previously described6 Brains from freshly decapitated rats were chilled and rapidly dessected into regions (the cerebral cortex, midbrain, thalamus, hypothalamus and striatum).

Specific angiotensin II binding was estimated by using a radioligand assay and ${ }^{3} \mathrm{H}$-labelled angiotensin II. Cellebral cell membranes, prepared by homogenization and centrifugation, were incubated with labelled angiotensin II $(0.08-0.15 \mathrm{nmol} / \mathrm{L})$ with absence or presence of an excess unlabelled angiotensin II ( ${ }^{5}$ ileu-angiotensin II, about $100 \mathrm{nmol} / \mathrm{L}$ ). Binding was estimated as ${ }^{3} \mathrm{H}$-labelled angiotensin II and the specific angiotensin II binding was determined from the difference in bound radioactivity in the presence or absence of an excess of unlabelled angiotensin II. Maximal binding capacity ( $\mathrm{fmol}$ $/ \mathrm{mg}$ of protein) and binding affinity (nM) was measured with Scatchard plot method6

\section{Assay Procedure for Estimation of Brain Con- verting Enzyme Activity}

Angiotensin-converting enzyme activity was determined by the spectrophotometric assay with hippuryl-1-histidyl-1-leucine (Protein Reseach Foundation, Osaka, Japan) as substrate? One unit of the enzyme activity is defined as $\mathbf{1 . 0}$ nmole of hippuric acid formed/min per $\mathrm{mg}$ of protein at $37^{\circ} \mathrm{C}$. All assays were performed in duplicate; coefficients of variation (CV) were as follows: intraassay, $3.8 \pm 1.5 \%$, and interassay, $4.5 \pm 2.0 \%$. Protein determination was performed by the method of Lowry et al?

Results obtained through the study are expressed as mean \pm SEM. For statistical analysis Student's t- or paired t-test was used.

\section{RESULTS}

\section{Blood Pressure}

1) Salt-Loaded Group

In the control rats, the systolic blood pressure did not change: from $104 \pm 12$ to $106 \pm 7 \mathrm{mmHg}$ in normotensive rats, and from $210 \pm 8$ to $212 \pm$ $4 \mathrm{mmHg}$ in spontaneously hypertensive rats. The systolic blood pressure of salt-loaded normotensive rats was $110 \pm 8 \mathrm{mmHg}$, which was approximately equal to that of the control rats. In contrast, the systolic blood pressure of salt-loaded spontaneously hypertensive rats elevated from $212 \pm 7$ to $246 \pm 12 \mathrm{mmHg}(\mathrm{p}<0.001)$.

2) Goldblatt One-Kidney Rats

In Goldblatt one-kidney rats, the systolic 
TABLE II SPECIFIC ANGIOTENSIN II BINDING ACTIVITY IN THE BRAIN REGIONS OF SALT-LOADED NORMOTENSIVE AND SPONTANEOUSLY HYPERTENSIVE RATS

\begin{tabular}{|c|c|c|c|c|c|}
\hline \multirow[t]{2}{*}{ Brain region } & \multirow{2}{*}{$\begin{array}{l}\text { Number of } \\
\text { experiment }\end{array}$} & \multicolumn{2}{|c|}{$\begin{array}{l}\text { Maximal binding capacity } \\
\text { (fmol/mg of protein) }\end{array}$} & \multicolumn{2}{|c|}{$\begin{array}{l}\text { Binding affinity } \\
(n M)\end{array}$} \\
\hline & & $N T R(n=8)$ & $S H R(n=15)$ & $N T R(n=8)$ & $\operatorname{SHR}(n=15)$ \\
\hline Cerebral cortex & 4 & $0.9 \pm 0.4$ & $0.5 \pm 0.2$ & $0.78 \pm 0.05$ & $0.75 \pm 0.03$ \\
\hline Midbrain & 5 & $2.1 \pm 0.5$ & $1.8 \pm 0.5$ & $0.79 \pm 0.06$ & $0.81 \pm 0.01$ \\
\hline Thalamus & 5 & $2.8 \pm 1.5$ & $3.5 \pm 1.2$ & $0.81 \pm 0.02$ & $0.79 \pm 0.03$ \\
\hline Hypothalamus & 5 & $2.3 \pm 0.4$ & $3.0 \pm 0.7$ & $0.77 \pm 0.04$ & $0.80 \pm 0.03$ \\
\hline Striatum & 4 & $1.5 \pm 0.3$ & $1.8 \pm 0.4$ & $0.76 \pm 0.03$ & $0.82 \pm 0.04$ \\
\hline
\end{tabular}

Each value is mean \pm SEM. NTR = normotensive rat, $\quad$ SHR = spontaneously hypertensive rat, Number of parentheses is number of rat examined.

TABLE III BRAIN ANGIOTENSIN-CONVERTING ENZYME ACTIVITY IN NORMOTENSIVE AND SPONTANEOUSLY HYPERTENSIVE RATS WITH AND WITHOUT SALTLOADING, AND IN GOLDBLATT ONE-KIDNEY RAT

\begin{tabular}{lccccc}
\hline \multirow{2}{*}{ Brain region } & \multicolumn{2}{c}{ Control } & \multicolumn{2}{c}{ Salt-loaded } & \multicolumn{2}{c}{ Goldblatt one-kidney } \\
\cline { 2 - 3 } & $N T R(n=10)$ & $S H R(n=10)$ & $N T R(n=8)$ & $S H R(n=15)$ & $(n=16)$ \\
\hline Cerebral cortex & $5.2 \pm 1.5$ & $4.7 \pm 1.5$ & $2.9 \pm 2.1$ & $4.3 \pm 2.5$ & $5.5 \pm 1.2$ \\
Midbrain & $3.5 \pm 2.2$ & $3.8 \pm 0.7$ & $7.2 \pm 3.1$ & $6.1 \pm 1.3 t$ & $4.2 \pm 1.1$ \\
Thalamus & $6.5 \pm 3.7$ & $2.8 \pm 0.9$ & $6.1 \pm 2.9$ & $2.2 \pm 1.4$ & $4.7 \pm 1.8$ \\
Hypothalamus & $4.9 \pm 3.3$ & $10.4 \pm 2.6^{*}$ & $5.7 \pm 2.2$ & $11.3 \pm 3.4$ & $6.5 \pm 1.7$ \\
Striatum & $5.5 \pm 3.1$ & $4.6 \pm 2.1$ & $6.6 \pm 1.8$ & $5.1 \pm 2.2$ & $6.1 \pm 0.9$ \\
\hline
\end{tabular}

$N T R=$ normotensive rat,$\quad S H R=$ spontaneously hypertensive rat .

Significance of differences: $* p<0.05$ as compared with the other areas of control $S H R$;

$t p<0.05$ as compared with the control value. Number of parentheses is number of rat examined.

blood pressure was $162 \pm 14 \mathrm{mmHg}$ at 4 weeks after renal artery clipping.

\section{Specific Angiotensin II Binding Activity to Brain Regions}

1) Comparison of Maximal Binding Capacity and Affinity between Normotensive and Spontaneously Hypertensive Rats.

As shown in Table I, the maximal binding capacity of angiotensin II receptor to angiotensin II (hereafter called as maximal binding capacity) was the highest of $3.0 \pm 1.1 \mathrm{fmol} / \mathrm{mg}$ of protein in the thalamus of the brain areas in normotensive rat, while it was the highest of $2.4 \pm 0.2 \mathrm{fmol} / \mathrm{mg}$ of protein in the hypothalamus in spontaneously hypertensive rat. However, the maximal binding capacity in each brain area of the normotensive rat was slightly greater than that of the spontaneously hypertensive rat.

Each receptor fraction was almost equal in binding affinity in both normotensive and spon- taneously hypertensive rats, and there was no significant difference of binding affinity between the normotensive and the spontaneously hypertensive rat.

2) Comparison of Maximal Binding Capacity and Affinity between Salt-Loaded-Normotensive and -Spontaneously Hypertensive Rats

As shown in Table II, the maximal binding capacity was the highest of $2.8 \pm 1.5 \mathrm{fmol} / \mathrm{mg}$ protein in the thalamus of the brain areas of normotensive rat. However, as compared to the rats without salt-loading the maximal binding capacity in each brain area was slightly smaller (Table II). In spontaneously hypertensive rat treated with salt, the maximal binding capacity was the highest of $3.5 \pm 1.2 \mathrm{fmol} / \mathrm{mg}$ of protein in the thalamus of the brain areas. When compared to the group without salt-loading the maximal binding capacity in the thalamus, hypothalamus and striatum was higher than in the same areas of the untreated group. 
Each receptor fraction was almost equal in binding affinity in both treated normotensive and spotaneously hypertensive rats, and there was no significant difference of binding affinity of receptor fraction between the two groups.

3) Specific Angiotensin II Binding Activity in Goldblatt One-Kidney Rat

The maximal binding capacity was $4.1 \pm 1.2$ $\mathrm{fmol} / \mathrm{mg}$ of protein in the thalamus, $2.3 \pm 1.0$ $\mathrm{fmol} / \mathrm{mg}$ of protein in the midbrain, $2.2 \pm 0.6$ $\mathrm{fmol} / \mathrm{mg}$ of protein in the hypothalamus, $2.0 \pm$ $0.5 \mathrm{fmol} / \mathrm{mg}$ of protein in the striatum, and $1.2 \pm 0.8 \mathrm{fmol} / \mathrm{mg}$ of protein in the cerebral cortex. Apparently, as compared to the normotensive control rats, the maximal binding capacity was greater in the midbrain area (Table I), but each receptor fraction was almost equal in binding affinity in the control rat and Goldblatt one-kidney rat.

\section{Angiotensin-Converting Enzyme Activity}

The results are summarized in Table III. In control normotensive rat, no significant difference in the enzyme activity was found in brain fraction. In control spontaneously hypertensive rat, on the other hand, the enzyme activity in the hypothalamus was $10.4 \pm 2.6$ units, which was significantly higher than in the other areas of the brain.

The enzyme activity in the midbrain of saltloaded spontaneously hypertensive rat was $6.1 \pm$ 1.3 units, which was significantly higher than that in the same area of the control rat.

In Goldblatt one-kidney rat, the enzyme activity in the hypothalamus was $6.5 \pm 1.7$ units, which was slightly higher than in the control rat. Similarly the activity of the enzyme in the other brain areas was almost equal to that of the control rat (Table III).

\section{DISCUSSION}

In the present study, we have demonstrated widely-distributed specific angiotensin II receptor in the brain in not only spontaneously hypertensive but also normotensive rat, which is consistent with the report previously described by Sirett et al?

As compared with normotensive rat, the maximal binding capacity of spontaneously hypertensive rat was smaller in each brain area studied. The depressed capacity of brain angiotensin II receptor observed in spontaneously hypertensive rat may give rise to speculation that this abnormality contributes to their hypertension. Hall- bäck and Folkow ${ }^{10}$ have suggested that in spontaneously hypertensive rat the genetic predisposition to hypertension is neurogenic in nature, which in the genetically hypertensive rat is supported by studies reporting increased sympathetic activity! 11

A reduced number of receptor site of brain angiotensin II receptors would explain the results of the ventricular perfusion studies of Ganten et al., who demonstrated increased angiotensin II concentrations in the cerebrospinal fluid of spontaneously hypertensive rat; a reduced population of angiotensin II receptor sites found in spontaneously hypertensive rat in the present study would be a natural consequence of increased btain angiotensin II ${ }^{13}$ This may be supported indeed by the fact that, when administered intraventricularly, angiotensin II antagonist which specifically competes with angiotensin II in occupying their receptors, ${ }^{14}$ shows an apparent hypotensive effectiveness in spontaneously hypertensive rat, while it fails to show the effect in normotensive rat ${ }^{15}$ It is therefore suggested that brain angiotensin II binding capacity changes inversely correlated with the brain renin-angiotensin system, though the mechanism by which the reduced receptor population occurs in spontaneously hypertensive rat is poorly understood in the present study.

Of interest in the present study is that the maximal binding capacity in the brain, especially in the thalamus and in the hypothalamus trended to increase in salt-loaded spontaneously hypertensive rat, while it did to decrease in salt-loaded normotensive rat. The cause underlying this difference remains obscure. One possible explanation may be that enhacement of the binding capacity of brain angiotensin II receptor follows development of hypertension induced by a high circulating sodium level in spontaneously hypertensive rat. It is also possible that the brain renin system may be more activated by salt intake in this hypertensive rat. Together, it is suggested that the increased brain angiotensin II binding sites and the renin system contribute to development of hypertension observed in salt-loaded spontaneously hypertensive rat. We have no direct evidence on this point, however.

In Goldblatt one-kidney hypertensive rat, the binding capacity in the brain, especially in the thalamus was greater than that in normal control rat. However, the maximal binding capacity in the other regions was almost equal to that of the control group. It is thus deduced that the increase 
in binding capacity is involved in hypertension observed in Goldblatt one-kidney hypertensive rat.

The high activity of angiotensin-converting enzyme in the brain that has been demonstrated in the present study is consistent with the results as previously reported in rat. ${ }^{16}$ Our data on the regional distribution of the enzyme activity, however, are not agreeable to that described by Yang et al., who investigated the regional and subcellular localization of the brain converting enzyme using normotensive rat from SpragueDawley strain and found the higher activity in the striatum and its microsomal fraction. Although we measured only total activity of the enzyme, a considerably high activity was found in the hypothalamus of spontaneously hypertensive rat. The cause of this discrepancy is not clear, but a difference of species studied may, in part, contribute to it.

It is noteworthy that the significant increase of the converting enzyme activity occurred with an elevation of blood pressure in salt-loaded spontaneously hypertensive rat, while there was no significant change in the enzyme activity in normotensive rat treated with the same manner. The site where enzyme activity increased was the midbrain. In seems likely therefore that, as compared with normotensive rat, production of the enzyme in the site is very sensitive to salt in spontaneously hypertensive rat, as well as the angiotensin II receptor site. Although we have no evidence that this elevation is involved in hypertension of spontaneously hypertensive rat, this local enhancement of converting enzyme activity is possibly specific in spontaneously hypertensive rat.

Since brain contains so many components, such as renin-like activity, angiotensin I and II, converting enzyme, and angiotensin II specific receptor, it is difficult to evaluate their physiological and/or pathological role in regulation of blood pressure unless these factors are exactly and simultaneously estimated. Further work to clarify this is now in progress.

\section{Acknowledgements}

The authors wish to thank to Miss Motoko Ajito for technical asistance.

\section{REFERENCES}

1. BUCKLEY JP: Central vasopressor actions of angiotensin. Biochem Pharmacol 26: 1, 1977

2. GANONG WF: The renin-angiotensin systein and the central nervous system. Fed Proc 36: 1771, 1977

3. SEVERS WB, DANIELS-SEVERS A: Effect of angiotensin II on the central nervous system. Pharmacol Rev 25: 415, 1973

4. FITZSIMONS JT: The effect on drinking of peptide precursors of shorter chain peptide fragments of angiotensin II injected into the rat's diencephalon. J Physiol (London) 24: 295, 1971

5. REID IA: Is there a brain renin-angiotensin system? Circ Res 41: 147, 1977

6. MIZUNO $\mathrm{K}$, SHIGETOMI S, MATSUI J, FUKUCHI S: Distribution and role of angiotensin II receptor in the brain of spontaneously hypertensive rat. Jpn Circul J 44: 403, 1980

7. LIEBERMAN $\mathrm{J}$ : Evaluation of serum angiotensinconverting-enzyme (ACE) level in sarcoidosis. $\mathrm{Am}$ J Med 59: 365, 1975

8. LOWRY OH, ROSEBROUGH NJ, FARR AL, RANDALL R: Protein measurement with Folinphenol reagent. J Biol Chem 193: 265, 1951

9. SIRETT NE, THORNTON SN, HUBBARD JI: Brain angiotensin II binding and central (Sar., $\mathrm{Ala}^{8}$ ) angiotensin responses in normal rats and the New Zealand strain of genetically hypertensive rats. Clin Sci 56: 607, 1979

10. HALLBÄCK MIL, FOLKOW BU: Physiopathology of spontaneous hypertension in rats. In Hypertension: Physiopathology and Treatment, ed by GENEST J, KOIW E, KUCHEL O, McGraw Hill, New York, 1977, p 507

11. PHELAN EL, SIMPSON FO, SMIRK FH: Characteristics of the New Zealand strain of genetically hypertensive (GH) rats. Clin Exp Pharmacol Physiol (Suppl 3) :5, 1976

12. GANTEN D, HUTCHINSON JS, SCHELLING P: The intrinsic brain iso-renin-angiotensin system in the rat: Its possible role in central mechanisms of blood pressure regulation. Clin Sci Mol Med 48: 265s, 1975

13. DOUGLAS J, CATT KJ: Regulation of angiotensin II receptors in the rat adrenal cortex by dietary electrolytes. J Clin Invest 58: 834, 1976

14. MIZUNO K, HARUYAMA K, NAKAJIMA K, FUKUCHI S: Clinical and experimental studies on angiotensin II receptor in arterial wall and adrenal cortex: Study with angiotensin II and its competitive antagonist. Jpn J Med 19: 25, 1980

15. PHILLIPS MI, MANN JFE, HAEBARA H, HOFFMAN WE, KIETZ R, SCHELLING $P$, GANTEN D: Lowering of hypertension by central saralasin in the absence of plasma renin. Nature (London) 270: 445, 1977

16. YANG HYT, NEFF NH: Distribution and properties of angiotensin converting enzyme of rat brain. $J$ Neurochem 19: 2443, 1972 